\title{
The Existence of Performance Art of Sandur in the Era Globalization
}

\author{
Hanindita Indira Suluh Pratiwi \\ Arts and Culture Education Studies Program, Postgraduate, University State of Surabaya, Jl. Ketintang, \\ Ketintang, Gayungan, Surabaya, 60231, Indonesia
}

\begin{abstract}
Sandur is a performance art form of traditional art. The existance of Sandur began reappeared by the community of Sukoharjo village in the district Tuban. Artist in the Sukoharjo village seeks to revive the art inherited by the ancestors. The existance of Sandur must be maintained and preserved for future generations can still see cultural heritage that exist in their respective regions. The main thing being studied in this research how form of presentation sandur art and the artist's effort to maintain the existence of Sandur. So this research was conducted with the aim of describes the presentation of art performances Sandur in the Sukoharjo village and for describes the artist's efforts in maintaining the existance of the Sandur in Sukoharjo Village. This research use qualitative approach and type of descriptive research. Data collection procedure is done by observation and interview metods. Data analysis activities start from data collection, reduction phase,persentation of data phase, and conclusion phase. Checking of data validity done with triangulation of sources and triangulation method. This research important to implement for seeing a change in the presentation of musical art slip and seeing the effort implement by the astist with adding an modern music insrument of Sandur art can made appreciation of society in Sukoharjo village became increasing. The art who have open mind of art can trough the cultural changes until this art can developing and survive in globalization era.
\end{abstract}

Keywords: Existance, performance, Sandur art.

DOI: $10.7176 / \mathrm{ADS} / 71-04$

Publication date:March $31^{\text {st }} 2019$

\begin{abstract}
Abstrak
Sandur merupakan seni pertunjukan yang berbentuk teater tradisional. Keberadaanya mulai dimunculka kembali oleh masyarakat Desa Sukoharjo yang ada di Kabupaten Tuban. Seniman yang ada di desa tersebut berupaya untuk menghidupkan kembali kesenian yang diwariskan oleh para leluhur tersebut. Keberadaan

Sandur saat ini harus dijaga dan dilestarikan agar generasi penerus tetap bisa melihat warisan budaya yang ada di daerahnya masing-masing. Hal utama yang dikaji dalam penelitian ini adalah bagaimana bentuk penyajian pertunjukan seni Sandur dan upaya seniman untuk tetap mempertahankan keberadaannya. Sehingga penelitian ini dilakukan dengan tujuan mendeskripsikan penyajian pertunjukan seni Sandur di desa Sukoharjo dan mendeskripsikan upaya seniman dalam mempertahankan keberadaan Sandur di desa Sukoharjo. Penelitian ini menggunakan pendekatan kualitatif dan jenis penelitian deskriptif. Prosedur pengumpulan data dilakukan dengan metode observasi dan wawancara. Kegiatan analisis data dimulai dari tahap pengumpulan data, tahap reduksi, tahap penyajian data, serta tahap penarikan kesimpulan. Pengecekan keabsahan data dilakukan dengan triangulasi sumber, dan triangulasi metode. Penelitian ini penting dilakukan untuk melihat adanya perubahan dalam penyajian musik seni Sandur dan melihat upaya yang dilakukan oleh seniman dengan menambahkan musik modern dalam pertunjukan seni Sandur dapat membuat apresiasi masyarakat desa Sukoharjo menjadi meningkat. Bagi seniman yang memiliki pemikiran terbuka terhadap sebuah kesenian akan dapat melalui perubahan budaya sehingga dapat berkembang dan bertahan di era globalisasi.
\end{abstract}

Kata Kunci : Eksistensi, Pertunjukan, Seni Sandur.

\section{INTRODUCTION}

The diversity of cultures that exist in Indonesia makes this country has a competitive society in creating and collaborating an art. Culture is a product of creative human activity. However, if creativity is produced and shaped, the possibilities of creativity can preclude new creativity. Because there is an inherent tension or interrelatedness between the processes of human life that constantly seek to express themselves in order to look creative and the objective cultural forms that must be demonstrated by the creative activity (Faruk, 2010: 37). Culture includes civilization, customs and traditions. The consequences of the existence of customary ordinances are born something tangible cultural products such as traditional dances that were born in the midst of the community supporters without known the process of its creation. Adat contains values and worldview for society. In adat there are prohibitions which are a must and can not be broken. The prohibition that has become a customary law, if it is violated for negligence factor then the sanction and punishment can be imposed (Bastomi, 1992: 12).

Javanese people interpret nature as a determinant of the safety or destruction of their lives, while the human 
is a source of security, so that the basic gotong-royong embracing their lives in the community. It is marked by the belief in the spirit of the ancestors, until finally a ceremonial ritual addressed to the spirit of the ancestors in the form of rituals-rituals .. Although now humans live in a modern era, but the culture and customs that have existed since hundreds- hundred years of the ancestors are still there and preserved, even to maintain its existence, human beings are not half-hearted in renewing it. But the culture can look not functional if the symbols and norms that are in it is no longer supported by the community (Kuntowijoyo, 1999: 7 ).

The development of a culture can be divided into the same region or scope. Cultural results that will be presented through a picture of a symbol agreed by the community supporters.

The development of a culture can be divided into the same region or scope. Cultural results that will be disampaikn through a picture of a symbol agreed by the community supporter. Arts including from one part of the seven elements of culture that has the beauty and values contained. Like a work of art that is an expression or embodiment of a thing formed through various elements, where each element is arranged through a series of structures that have interrelated relationships with each other, to form a visible embodiment of the visual (Hidayat, 2005: 26) .The art form itself has its own characteristics and uniqueness. Just like traditional art which is the arts of the region is one part of national culture that is maintained and preserved. The performing arts of Sandur is one of the regional arts that until now still trying to be maintained by the people, namely the people of Tuban. Although the performing arts of Sandur are now on the verge of extinction.

Sandur art show in Tuban has similarities with Sandur art that exist in Bojonegoro and Lamongan area. Sandur word stems from anecdotes "messy ngedur", because the performing arts Sandur staged overnight or overnight ie from 20.00-03.00 in the morning.

The existence of Sandur art performance which is a legacy of the ancestors of its present existence is already beginning to become extinct. Art that developed in the middle of this agrarian society lifting material performances that many take from the symbols of agriculture. As in the dialogue, Sandur's art show presents a story with the theme of paddy fields, farms and the life of farmers in the countryside. Sandur performing arts staged by using dance moves, using a mixed Javanese language dialogue of Javanese ngoko and java kromo language, but it also uses tembang-song or song of Java. Along with the rapid development of the times, emerged various forms of modern art that looks more attractive, because people basically have the nature always want a change in something that has been considered long. The result of the existence of the art of Sandur performing arts which is the inheritance of the ancestors was evicted, because not necessarily can survive. So do not be surprised if the younger generation in Tuban Regency so many who do not know the performing arts Sandur has not even seen the performance.

Sandur's art performance is considered not able to provide economic value to meet the needs of life for the players, it is due to the shift in traditional art as the times. Sandur art performance is a traditional art form of traditional theater. The sandur has the same shape as other traditional theaters that is simple in its presentation, but more identical to the stories about human life and agriculture. Sandur art performance has experienced a golden era in the era of the 1960s. In this era the number of Sandur groups are quite a lot. In the 1960s, almost every sub-district in Tuban district had Sandur groups. Sandur is a live art performance that thrives in Tuban Regency. Sandur art performance can be performed after harvest time as an expression of gratitude from farmers. They are grateful for the harvest that has been obtained at the same time have the hope of harvest in the next planting season will get abundant results back.

The author conducted research on the development of Sandur art show that is found in Sukoharjo Village, Parengan District, Tuban Regency. In this village, the community is digging awareness and having an important role in maintaining the existence of Sandur art by forming groups. With the awareness that is in each individual they happily offer themselves and join the Sandur arts group and practice spirit. Until now there are two groups ready to perform Sandur art show if requested. The art form of Sandur has changed. Determining where changes in a traditional arts should be careful. Changes may be made, but provided that the values contained in the art can not be removed. The change of presentation of Sandur art performed by the Sukoharjo community is nothing but to attract the attention of the audience and also follow the development of the fast-moving era, without having to abandon the traditional values contained therein. This change in presentation is the problem and is observed by the writer and how the role of artist and community of Sukoharjo village can make the form of change. Usually they will perform when asked to perform such as performances in clean village events, alms earth, and the celebration of the big days.

The study of the theory or concept used in this research is the concept of existence that is used to reinforce the existence of artistic performances of Sandur that has re-emerged in the midst of the support community due to the efforts made by the artist. Furthermore, the use of acculturation theory that is used to explain changes in presentation of art performances Sandur. Research on Sandur art show in Sukoharjo village aims to get data about Sandur art show performance in Sukoharjo village as well as to invite the society and young generation to know and preserve the local culture which is currently declining amid the globalization.

The method used in this research is qualitative descriptive. Qualitative methods are used to obtain in-depth 
data, a data that contains meaning. Meaning is the actual data, the exact data and is a value behind the visible data (Afiffudin and Saebani, 2012: 59). The meaning that attempted to show in this research is the existence of Sandur art performance in 2010-2018. The type of research used is descriptive, ie to describe the change of presentation of Sandur performing arts in 2010-2018 in Sukoharjo village and to describe the artist's efforts in maintaining Sandur existence in the year 2010-2018 in Sukoharjo village.This article is the result of research from the author and some previous relevant research. Relevant earlier studies are of a reference nature only. This article has also not been published in other journals and not the result of plagiarism.

\section{METHOD}

This study aims to get data about the existence of art sandur in Sukoharjo Village. The method used is qualitative descriptive. Qualitative method is used to obtain in-depth data. Type of research used is descriptive, that is to describeof presentation of art Sandur in year, 2010-2018 and to describe the efforts of artists to maintain the existence of sandur in year 2010-2018 in Sukoharjo village

\section{DISCUSSION}

\section{Presentation Of Art Sandur in Sukoharjo Village.}

Various traditional arts in East Java, especially in the district of Tuban, has various types of art that color the nation's culture one of which is Sandur art performance. Performances of Sandur Art is a traditional art that exist in East Java developing in the north coastal area with different characters in each coastal region. The art of Sandur show is usually staged to express gratitude after the harvest season arrives, this tradition has been around since time immemorial.

Sandur art performance is a traditional art form of theater. In Sandur art performance there are elements of theater, humor, dance and using a simple musical accompaniment. The theatrical elements in the Sandur art show contain folk speech such as the accent, nickname, the traditional rank and the noble title. People's prose stories such as myths, legends, fairy tales, and people's songs (Sukatman, 2009: 6).

An expert argues rather strictly that oral tradition is all art, performance, or games that use oral speech. If an art is not used or not accompanied by oral speech excluding oral tradition. Conversely, if a story is not ditradisikan (demonstrated) in front of the support community, not including oral tradition, although it includes oral tradition and potential to be an oral tradition (sabrani, 2000: 25). Based on the above discussion it can be understood that oral tradition is a show that is delivered verbally, whether still active or passive. Sandur performing arts that developed in the district of Tuban is a form of folk art in the form of theater and has a simple, spontaneous and united in the life of supporters (Kasim, 1981: 39).

In addition to drama, Sandur Performing Arts also contains music and dance art. However, in the current development of Sandur has undergone changes in the opening and appearance of the music. Art Sandur which originally started with the opening of Jaranan dance which essentially only as a filler waiting for the core story of Sandur, now the community of Sukoharjo village begins with gending campursari. Art music on Sandur which initially uses the traditional tools of gamelan, now in accordance with the progress of the modern era has been inserted by other musical instruments that organ without removing the traditional musical instruments. This is in accordance with the concept of acculturation (Koentjaraningrat, 1990: 248) which states that, acculturation is a social process that arises in a group of people with a particular culture they have and are faced with elements of foreign culture. So that foreign culture will gradually be accepted and processed into its own culture without causing the loss of the original cultural elements of the group itself. This change is done because of the influence of the consumption of people who are more happy with the orchestra or dangdutan performances that use the music organ as accompanist. The Sukoharjo community's higher interest in seeing Sandur's performing arts with organ accompaniment compared to the pure Sandur performing arts is traditionally sung as the Sandur tend to be monotonous and boring. This is in accordance with (Suryajaya: 2015: 66) that natural pleasure is possible because the intrinsic component of music has actually imitated the character and patterned parralel with the soul. However, these descriptions are inferior because they do not require any kind of knowledge in the listener other than particular for certain sounds. The changes made only around the opening and art of music, the values of the traditional storyline that characterize the Sandur art performance are maintained by the people of Sukoharjo village as a form of cultural heritage.

After the campursari song finished, then resumed a scene called frontman, a scene that contains a joke. After the frontman scene then enter the main event sandur. Sandur show story is played by figures Balong, Pethak, Cawik, and Tangsil. The scene of Sandur performing arts performances in Sukoharjo society begins with the sad endhogs that symbolize humans while still being an embryo, kendhi bancik when humans are still in the stage of childhood, knee knee when humans have reached maturity, and the shoulder bancik is a symbol when humans have reached high stage, meaning the desired desire has been achieved, such as getting a job. After the scene is selesei played then the last stage of the show is Kalongking. Kalongking is an attraction of a player who walks on a rope with a height of about 17 meters from the ground, both ends of the rope are tied to a bamboo rod 
that is plugged in the ground in the middle of the field. When you have been in the middle of the rope the culprit is directly doing tapa batong with the head position at the bottom with the feet hooked on the rope. Seleseinya performances kalongking, then ended up also performing arts Sandur performances.

\section{The Artist's Efforts To Maintain The Existence Of The Art Of Sandur In Sukoharjo Village.}

Humans have a close relationship with culture, as well as to preserve the human culture is very important role. Because, humans who create culture, and humans also must maintain, maintain, and preserve the culture. In preserving and preserving the local culture that exists in society can be done in various ways. As well as the efforts made by artists in Sukoharjo village, in maintaining cultural preservation. Sukoharjo village is one of the developing villages with artists living in the area. He is Eko Kasmo, or his nickname is Mr. Eko. A Tuban original artist, born on July 23, 1971. Chairman of Ngrepto Laras's studio, who is an activist of traditional arts, one of which is Sandur. In the house which is also called the studio there is a complete set of gamelan tools and also other musical instruments such as drums, guitars, and bass. Many students of elementary, junior and senior high school students who come to practice every afternoon and Sunday. Usually he adjusts the schedule of children to practice.

Not only from among the school students who study the arts at Eko studio, but he also plays a big role for the people of Sukoharjo, which is able to give a positive influence to maintain the existing art. Until finally Sukoharjo village has two members of the Sandur performing arts group formed by Eko through village deliberation and provide opportunities for anyone who is willing and willing to become a member of Sandur art performance. Indirectly the existence of artists can affect a community to re-explore and display the existing art, even the people of Sukoharjo village who are members of art groups diligently practicing at Eko sanggar. Starting from the practice of playing the characters contained in the show Sandur, until finally Eko initiated a change from the art show Sandur. As explained, Eko's effort to add organ music and make his musical compositions become accessible to all societies in the Sandur art performance is deemed to attract the public's appreciation for enjoying the new Sandur art performance. The fact is in accordance with the concept of existence expressed (Dagun, 2012: 56) that, existence assumes human existence is not static, man will always move from possibility to reality. The process changes when it becomes possible today, tomorrow will become a reality, because humans have freedom then this developmental movement is all based on the man himself. Thus, the Sandur art show in Tuban which originally had the same form of performance in other areas now has its own identity that is able to captivate the audience due to the efforts of the artist in Sukoharjo village. It is also in accordance with the statement (Suryajaya, 2015: 597) that as an artist, he assumes another historical task: seeking a new artistic-formal achievement apart from the sociological interpretation of the form he produced. Being a socialist artist means living in the constant tension between creating a free form.

Now, Sandur who has long disappeared from the performing arts in the Tuban region, began to touch again by the people Sukoharjo it. Until finally Sandur can be displayed again at certain celebrations and events such as people who have a celebration with a lot of audience enthusiasm. From these observations seen the efforts of the community to re-popularize the art of performing Sandur. Now the art show of Sandur seems to start showing its existence every year in 2010, 2012, 2013, 2014, 2015, 2016, 2017 and the last perfomance in 2018. Eko's efforts as an artist took the initiative to insert modern music organ as a companion song during the show took place appreciation from the public. The change of the instrument instrument is nothing but to encourage the public to be more interested, and it is considered quite fruitful with the number of spectators at Sandur show every year increasing.

\section{CONCLUSION}

Art performances Sandur is one of the regional arts that until now trying to be maintained by the community supporters of the village community Sukoharjo in Tuban District even though the art is on the verge of extinction. The existence of art performances Sandur which is the art of inheritance from the ancestors and old people of the past now its existence has begun to be abandoned. Art that was born in the middle of agrarian society and almost extinct existence and existence lifting device and material performances that many symbolize agriculture. The changes made in the opening and art of music, The values of the traditional story line that characterized the art of Sandur is maintained by the people of Sukoharjo village as a form of cultural heritage. Seen the efforts of the community to re-popularize the art of Sandur in accordance with the opinion, where individuals participate in the process of formation and maintenance of social facts, which is Sandur as an art that has been passed down from generation to generation.

Human must synergize between nature, human, and God through tolerance of each other and love between people and different human status.

\section{REFERENCES}

Afifuddin dan Saebani, Beni Ahmad. 2012. Metodologi Penelitian Kualitatif. Bandung: PUSTAKA SETIA. 
Bastomi, Suwaji. 1992. Seni dan Budaya Jawa. Semarang: IKIP Semarang Press.

Dagun, Save. M. 2012. Sosiologi dan Perubahan Masyarakat. Jakarta: PT: Pustaka Jaya.

Emzir. 2010. Metodologi Penelitian Kualitatif: Analisis Data. Jakarta: PT RAJAGRAFINDO PERSADA.

Faruk. 2014. Pengantar Sosiologi Sastra. Yogjakarta: PUSTAKA PELAJAR.

Hidayat, Robby. 2005. Wawsasan Seni Tari Malang. Jurusan Seni dan Desain. Fakultas Sastra. Universitas Negeri Malang.

Kasim, Ahmad. 1981. Teater Rakyat di Indonesia. Jakarta: Departemen Pendidikan dan Kebudayaan.

Konjtaraningrat.1990. Pengantar Ilmu Antropologi. Jakarta: PT Rineka Cipta.

Kuntowijoyo. 1999. Budaya dan Masyarakat. Yogjakarta: PT Tiara Wacana.

Sukatman. 2009. Butir-Butir Tradisi Lisan Indonesia. Yogjakarta: LaksBang PRESSindo.

Suryajaya, Martin. 2015. Sejarah Estetika. Yogjakarta: Gang Kabel. 